\title{
INFLUENCE OF REDUCING AGENTS AND SURFACTANTS ON SIZE AND SHAPE OF SILVER FINE POWDER PARTICLES
}

\author{
Stevan P. Dimitrijević ${ }^{1 *}$, Željko J. Kamberović ${ }^{2}$, Marija S. Korać ${ }^{2}$, \\ Zoran M. Anđić ${ }^{3}$, Silvana B. Dimitrijević ${ }^{4}$, Nikola S. Vuković ${ }^{5}$ \\ ${ }^{1}$ Innovation Center of the Faculty of Technology \& Metallurgy, \\ University of Belgrade Karnegijeva 4, Beograd, Serbia \\ ${ }^{2}$ Faculty of Technology \&Metallurgy, University of Belgrade \\ Karnegijeva 4, Beograd, Serbia \\ ${ }^{3}$ Innovation Center of the Faculty of Chemistry, University of Belgrade, \\ Studentski trg 12-16, Beograd, Serbia \\ ${ }^{4}$ Mining and Metallurgy Institute Bor, Zeleni Bulevar 35, Bor, Serbia \\ ${ }^{5}$ Faculty of Mining and Geology, University of Belgrade, Djusina 7, \\ Beograd, Serbia
}

Received 14.01.2014

Accepted 05.05.2014

\begin{abstract}
Silver fine powder with different shapes and sizes were prepared by chemical reduction and characterized by scanning electron microscope. In this paper was presented the method for the preparation of the fine Ag powder with particles size smaller than $2.5 \mu \mathrm{m}$ with suitability for the mass-production scale. Reduction was performed from nitrate solution directly by vigorous stirring at room temperature by three different reduction agents, with and without presence of two dispersants. Scanning electron microscopy revealed the preferred size of the particles obtained in all experiments with aim of the protecting agent. Larger particles and wider size distribution were obtained without surfactants although with average size of about $1 \mu \mathrm{m}$ and small quantity of larger clusters of primary particles that is out of the fine powder classification. High purity, $99.999 \%$, of silver was obtained in every experiment. Key words: silver, fine powder, chemical reduction, surfactants.
\end{abstract}

\section{Introduction}

Silver and silver alloys are used extensively from art to numerous industrial and commercial applications, which are determined by its exceptional characteristics. It is well known that the pure silver has the highest thermal and electrical conductivity and

*Corresponding author: Stevan Dimitrijević: stevad@gmail.com 
the lowest contact resistance of any metal. Silver also has one of the highest optical reflectivities.

Silver powder plays an important role in the sintering. General use for powder metallurgical processing of silver is similar to other precious metals applications such as jewellery, dentistry and electronic; although silver, particularly, has bulk usage in solder/braze pastes and contacts. Use of ultra-fine powders in sensors, which is the 'high-tech' end of the solder type applications, is an area of application for all precious metals including silver [1]. Another silver powder uses include applications: batteries, brazing powder and fluxes, catalysts, conductive coatings, inks and pastes, diamond tools, EMI/RFI shielding, high thermal conductivity materials (pastes), masterbatch, sintering additives and others. For these, usual industrial purposes, $-200,-200+400$ or -400 mesh silver powder is used. It is produced by common powder metallurgy methods like atomisation or electrolysis [2].

In the few past decades, the synthesis of nanocrystals, particles ranging in size from $1 \mathrm{~nm}$ to $100 \mathrm{~nm}$, has been intensively studied. Nanoparticles (NPs) exhibit outstanding electrical, optical, magnetic, etc. properties that cannot be revealed by their bulk counterparts [3]. NPs are very important not only due to their fundamental scientific interest but also because of their many useful applications. Silver nanoparticles can be used as antibacterial materials, antistatic materials, cryogenic superconducting materials, biosensor materials, catalytic materials, photovoltaics (solar cells) and various electronic applications. Common synthetic methods of silver nanomaterials are chemical reduction, photochemical method, ultrasonic-assisted reduction, electrochemical method, irradiating reduction, biochemical method, microemulsion method, and so on. Foremost among them is chemical reduction for production of large quantities of nanoparticles in relatively short periods of time [4].

It means that syntheses of silver nanoparticles are well developed processes for small size production but with high technical requirements and expenses for the mass scale production. Price of submicronic silver powder rise double till the size of about $150 \mathrm{~nm}$ but then exponentially and could be up to ten times more for nanoparticles less than $10 \mathrm{~nm}$ [5]. Not only price but the expenses similar depend on the particle size. Even with promising results for the ultrasonic spray pyrolysis, which could enables an easy control of the powder morphology and the excellent availability of cheap precursors at acceptable costs, with a great potential to be the future solution for the synthesis of silver nanopowder [5], nanopowder use is still limited by its price.

Fine silver powder could be used instead of coarse (2.5 to $10 \mu \mathrm{m})$, with the quality improvements and slightly higher costs. This is why the interest for the production of fine silver powder (less than $2.5 \mu \mathrm{m}$ ) is interesting especially because it can be used in many applications where nanoparticles are preferable but not required including electrically and thermally conductive paste, electrical contact alloys, solid oxide fuel cells, chemical catalysts, etc [6].

Alloys for electric contact have been made from silver alloys, $\mathrm{Ag}-\mathrm{CdO}$ which is still most using one but in the process of replacement with other silver alloys, due to the high toxicity of cadmium, especially its vapour during the application [7]. There are two technological options to obtain contact materials: (i) ingot metallurgy, where the preparation of metal oxide in the matrix is achieved by internal oxidation process; (ii) powder metallurgy, which in addition to direct internal oxidation of compacted pieces provides the possibility for the oxidation process in the energy grinding mills, mixing 
oxide particles with particle matrix, compaction, sintering, etc. [7, 8]. Similar, ideal silver powder for the conductive pastes is one with non-agglomerated crystalline particles with a narrow size distribution and $1-2 \mu \mathrm{m}$ or sub-micrometer size $[9,10]$.

Many methods, such as chemical reduction, photochemical or radiation chemical reduction, the sonochemical method, and the polyol method, are being applied currently to prepare fine and ultrafine silver powders [11].

Among the preparation methods of nano Ag particles or micro-sized spherical silver powders, wet-chemical reduction route is preferred due to the advantage of controllable size and shape of the particles. A variety of wet-chemical methods were developed to prepare silver powders and most of them focused on the synthesis of nano Ag particles. However, they can be adapted to synthesis of fine powders and several researches reported the preparation of the micro-sized spherical Ag powders, with considerable interests in its synthesizing during the past decade because of its excellent properties but reasonable price [6].

Various reducing agents are used for chemical reduction of $\mathrm{Ag}^{+}$, mainly from aqueous $\mathrm{AgNO}_{3}$ solutions. The most often used reducants are: hydrazine hydrate, ascorbic acid, formaldehyde and water-soluble formates, trisodium citrate, glycose, KNa-tartrate and hydroquinone in the presence of different and numerous, mainly polymeric, stabilizers. Glycerol and ferrous ions were considered as the reducing agent for the $\mathrm{Ag}^{+}$from sulphate solutions and ethylene glycol from carbonate solutions. Protecting agent, stabilizers or dispersants are usually surfactants and common ones are: polyvinylpyrrolidone (PVP), polyvinil acetate (PVA), orthophenylenediamine nmethyl-2-pyrrolidone (NMP), triethanolamine (TEA), sodium dodecyl sulfate (SDS) and gum arabic $[6,10-13]$.

In this paper, silver particles were synthesized from silver nitrate solution with hydrazine hydrate and ascorbic acid as reducing agent. Polyvinylpyrrolidone and sodium dodecyl sulfate were used as dispersant. Chemical reduction is simple and efficient method for industrial production and do not require expensive equipment. Experiments were adapted to such conditions and no special apparatus were used.

\section{Experimental}

In order to enhance reduction process and to obtain fine silver powder reduction was performed in two steps. First step was the reduction of $\mathrm{Ag}^{+}$by $0.1 \mathrm{M}$ hydrazine hydrate in excess from $0.1 \mathrm{M} \mathrm{AgNO}_{3}$ solution. Silver nitrate solution was obtained by dissolving silver, purity of $99.9 \%$, in nitric acid p.a. quality and $5.0 \mathrm{~mol} / \mathrm{dm}^{3}$ concentration and then diluted to $0.1 \mathrm{M} \mathrm{AgNO}_{3}$. The powder from the first step (reduction) was used for all experiments in the second step, re-precipitation. Six rereduction process, were preformed after the same procedure for dissolution of silver and adjustment to $0.1 \mathrm{M} \mathrm{AgNO}_{3}$ concentration. In all experiments reducing agent was added slowly, drop by drop, with vigorous mixing.

Preparations of the $\mathrm{Ag}$ fine powder by re-reduction were performed by:

1) Hydrazine hydrate $0.1 \mathrm{M}$, the same volume $(200 \mathrm{ml})$ as $0.1 \mathrm{M} \mathrm{AgNO}_{3}$ and without addition of surfactant.

2) Hydrazine hydrate $0.1 \mathrm{M}$ the same volume $(200 \mathrm{ml})$ as $0.1 \mathrm{M} \mathrm{AgNO}_{3}$ with $2 \%$ PVP as protecting agent (surfactant).

3) Hydrazine hydrate $0.1 \mathrm{M}$ the same volume $(200 \mathrm{ml})$ as $0.1 \mathrm{M} \mathrm{AgNO}_{3}$ with $0.05 \mathrm{M}$ SDS, $2.884 \mathrm{~g}$ in $200 \mathrm{ml}$, as protecting agent. 
4) Ascorbic acid $0.1 \mathrm{M}(3.522 \mathrm{~g})$ in the same volume (200ml) as $0.1 \mathrm{M} \mathrm{AgNO}_{3}$ with $2 \%$ PVP as protecting agent.

5) Ascorbic acid $0.1 \mathrm{M}$ the same volume $(200 \mathrm{ml})$ as $0.1 \mathrm{M} \mathrm{AgNO}_{3}$ with $0.05 \mathrm{M}$ SDS, as protecting agent.

The final concentration of all surfactant at the end of reduction, in experiments $2-5$, was the approx. half of the starting ones stated above.

6) Combination of sodium citrate and ascorbic acid. Firstly, in the $200 \mathrm{ml}$ of $0.1 \mathrm{M}$ $\mathrm{AgNO}_{3}$ the $100 \mathrm{ml}$ of $0.2 \mathrm{M} \mathrm{HOC}(\mathrm{COONa})\left(\mathrm{CH}_{2} \mathrm{COONa}\right)_{2} \cdot 2 \mathrm{H}_{2} \mathrm{O}(5.882 \mathrm{~g}$ of trisodium citrate dihydrate in $100 \mathrm{ml}$ of water) was added the same way as other solutions, and after a minute of mixing, $200 \mathrm{ml}$ of $0.1 \mathrm{M}$ ascorbic acid was added in the solution.

Temperature was $25 \pm 1^{\circ} \mathrm{C}$ and homogenizations of the solutions were performed using standard laboratory magnetic stirrer at $600 \mathrm{rpm}$. The obtained silver powder for all experiments was filtered, rinsed with bidistilled water and absolute ethanol and dried at $110^{\circ} \mathrm{C}$ for two hours.

\section{Experimental apparatus}

Analytical balance (Shimadzu AX 200) with a maximum load of $200 \mathrm{~g}$ and $\mathrm{d}=0.1 \mathrm{mg}$ was used for the measurement of chemicals. The $\mathrm{pH}$ of the electrolyte was monitored using a pH meter (HANNA-Aldrich Sigma, Model C3724 1EA). The apparatus used in reduction experiments were: temperature adjustable magnetic stirrer, with $\pm 1.0^{\circ} \mathrm{C}$ deviation, various laboratory glassware, Erlenmeyer flasks and beakers form 400 to $1000 \mathrm{ml}$, Büchner (vacuum) flask and electrical laboratory drier.

\section{Reagents}

For silver reduction following chemicals were used: nitric acid p.a. (Merck, Germany), hydrazine hydrate p.a. (Merck, Germany), ascorbic acid p.a. (Merck, Germany), polyvinylpyrrolidone pharmaceutical (USP) grade (Ashland/ISP, USA), sodium dodecyl sulfate (SDS) pharmaceutical (Ph. Eur.) grade, (Cognis, Germany), trisodium citrate dihydrate p.a. (Merck, Germany). Absolute ethanol p.a. (Zorka, Serbia) for silver powder rinsing was used. In all experiments deionized or double distilled water with max. $1 \mu \mathrm{S} / \mathrm{cm}$ conductivity were used.

Analysis methods

Inductively coupled plasma atomic emission spectroscopy (ICP-AES) and Atomic Absorption Spectrophotometry (AAS)

Determination of silver purity and monitoring of all stages of the process:

Inductively coupled plasma atomic emission spectroscopy (ICP-AES, Produced by: Spectro, Model: Ciris Visio, Detection limit: $<0.0001 \mathrm{~g} / \mathrm{dm}^{3}$ ) and Atomic Absorption Spectrophotometer (AAS, Produced by: Perkins \& Elmer, Model: 403, Detection limit: $\left.<0.0001 \mathrm{~g} / \mathrm{dm}^{3}\right)$.

\section{Scanning electron microscopy (SEM) with energy-dispersive spectrometry (EDS)}

Scanning electron microscope (SEM model: JOEL JSM- 6610LV operated at $20 \mathrm{keV}$ ) were used for determination of particle size and morphology of the silver powder. Before the examination, the samples were not treated in the ultrasonic bath with aim to deaglomeration of the powder. Chemical compositions were determined using the Energy Dispersive X-ray Spectroscopy (EDS). The EDS spectrums for silver powder were recorded using the X-ray spectrometer, attached to the scanning electron 
microscope. The EDS image shows a place where the chemical composition of silver powder was determined.

Granulometric composition (particle size distribution; particle size analysis for SEM) of powders were determined by SEM software ImageJ (National Institutes of Health USA) and capability of ImageJ for measuring distance directly from the image. Fifty particles per sample were measured. The morphology of silver powder was studied using the SEM imaging.

\section{Results and Discussion}

Silver dissolution by means of nitric acid is shown in the reaction (1). The reaction is faster in diluted nitric acid (about $30 \%$ by weight; in this case $5.0 \mathrm{M} \mathrm{HNO}_{3}$ or $27.15 \%)$.

$$
3 \mathrm{Ag}+4 \mathrm{H}^{+}+\mathrm{NO}_{3}^{-} \rightarrow 3 \mathrm{Ag}^{+}+\mathrm{NO}+2 \mathrm{H}_{2} \mathrm{O}
$$

After dissolution of silver, which is performed in almost stoichiometric manner, it is important to remove excess nitric acid from solution with moderate heating on a sand bath. It was carried out until there were no more yellow fumes from nitrogen oxides. This provides that solution has $\mathrm{pH}$ nearly as $\mathrm{AgNO}_{3}$ dissolved in ultra pure water with same $\left(0.1 \mathrm{~mol} / \mathrm{dm}^{3}\right)$ concentration, $\mathrm{pH}$ value were between 4.5 and 4.8 in experiments, which is very near of the solution from the salt $(\mathrm{pH} \approx 5.0-5.5)$.

Fine powder of silver with different shapes can be easily prepared by controlling the reaction conditions, however, after the extraction in powder form, the obtained, primarily particles tend to aggregate to form lager particles. In this manner formation of final particles could proceed through a two-stage mechanism, were high reaction ratio of the reduction results in small and easily separable particles [13]. Traditionally models of coagulation and nucleation usually assume diffusion transport and microscopic nucleation processes where the size distribution and morphology of silver particles are mainly affected during the second stage $[10,14]$ but modern models show that the growth is multistage kinetic controlled process $[13,14]$.

In order to prevent primary particles from assembling into larger particles during their growth stage, the primary particles should be protected by a suitable dispersant. Used surfactants are proved in practice, as stated above, and can control the morphology and size distribution of silver particle.

\section{Reduction with hydrazine hydrate}

Reaction of $\mathrm{Ag}^{+}$reduction by hydrazine (for hydrated form, reaction is the same) is shown in eq. (2), in weak basic conditions, due to base properties of $\mathrm{N}_{2} \mathrm{H}_{4} \cdot \mathrm{H}_{2} \mathrm{O}$.

$$
4 \mathrm{Ag}^{+}+\mathrm{N}_{2} \mathrm{H}_{4}+4 \mathrm{OH}^{-} \rightarrow 4 \mathrm{Ag}+\mathrm{N}_{2}+4 \mathrm{H}_{2} \mathrm{O}
$$

Reaction 2 lowers the $\mathrm{pH}$ of the solution but due to low concentrations of the reactants it remain in weak base area even without buffered; $\mathrm{N}_{2} \mathrm{H}_{4} 0.1 \mathrm{M}$ solution has $\mathrm{pH}=10.68$ (measured value; theoretically, calculated value is 10.74 ) which is more base than $\mathrm{AgNO}_{3}$ is acid. Since identical concentration of the solutions, reducing agent is added in four time excess, according to the reaction (2). For the higher concentrations of $\mathrm{AgNO}_{3}$ solutions (with lower $\mathrm{pH}$ ), base should be added to adjust $\mathrm{pH}$ in weak base 
region, usually with few drops of diluted $\mathrm{NaOH}, \mathrm{KOH}$ or ammonium hydroxide $\left(\mathrm{Ag}^{+}\right.$ would be complexed in this case). Otherwise, hydrazine would be consumed in the reaction with an acid.

Reduction by hydrazine hydrate has been used for mass scale (industrial) production of commercial silver powder, for decades. It is sales like standard offer for the massive powder metallurgy purposes along with the ones produced by electrochemically or atomisation and usual granulometric composition $-200+400$ mesh $[2,15-16]$.

The reaction could be influenced by slowing down, concentration of reactants and $\mathrm{pH}$ value of the solution. Fine powders could be easily prepared by N2H4 H2O even without surfactants and is often consider as preferred reducing agent where spherical silver powder with an average particle size of about $150 \mathrm{~nm}$ could be achieved [11].

\section{Hydrazine hydrate without surfactant}

Single reduction is convenient for industrial production of silver powder with average size of particles about $50 \mu \mathrm{m}$. It is rarely used for fine powder preparation even when repeated. Results shows that carefully controlled process can yield fine powder of silver although with worse quality compared to reduction which uses dispersant. It could be very interesting for the recycle processes, in the aim of more valuable final product.

Individual particles larger than $2 \mu \mathrm{m}$ and many agglomerate, cluster structured, of several particles with about $0.5 \mu \mathrm{m}$ in size are present in the Figure 1. The most prominent cluster is in the lower right of the picture near the corner and has length of $3.1 \mu \mathrm{m}$ but also many small individual particles below $0.6 \mu \mathrm{m}$ are present. The statistical analysis of the particle size given in Table 1. confirm wide distribution of particle size. Shapes of the particles are spherical or irregular.

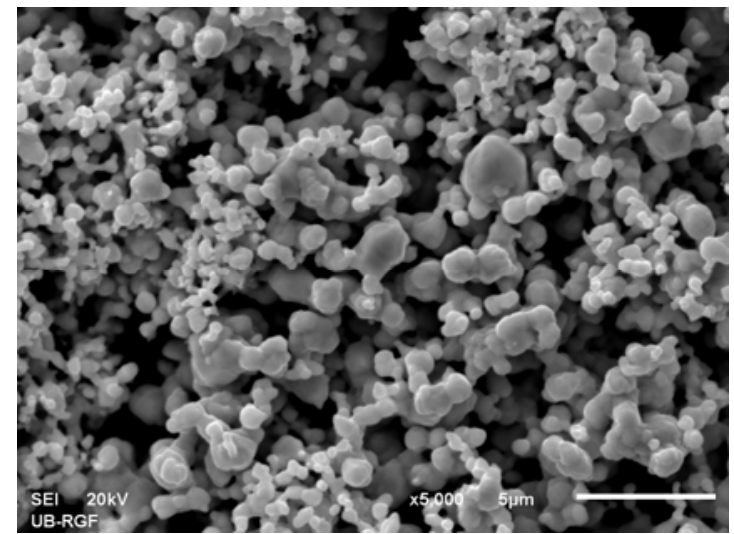

Fig. 1. SEM image of silver powder obtained with double reduction by hydrazine

It is obvious that absence of dispersant results in bad distribution of particle size and numerous clusters. Although more than $90 \%$ (Table 1) of particles belong to fine powder classification, the powder cannot be used for such purposes. Nevertheless it is still silver powder of high quality and particles below $5 \mu \mathrm{m}$. 
Table 1. Statistical analysis of the particle sizes obtained with double reduction by hydrazine, given in the Figure 1.

\begin{tabular}{|c|c|c|c|c|c|c|c|}
\hline \multirow{2}{*}{$\begin{array}{l}\text { Reduction } \\
\text { agent }\end{array}$} & \multirow{2}{*}{$\begin{array}{l}\text { Average } \\
\text { particle } \\
\text { size, } \mu \mathrm{m}\end{array}$} & \multirow{2}{*}{$\begin{array}{c}\text { Standard } \\
\text { deviation, } \\
\mu \mathrm{m}\end{array}$} & \multirow{2}{*}{$\begin{array}{l}\text { Particle } \\
\text { size, from } \\
\text { to, } \mu \mathrm{m}\end{array}$} & \multicolumn{3}{|c|}{$\begin{array}{c}\text { Particle size } \\
\text { distribution, } \mu \mathrm{m}\end{array}$} & $\begin{array}{c}\text { Silver } \\
\text { purity, \% }\end{array}$ \\
\hline & & & & D10 & D50 & D90 & \multirow{2}{*}{$\begin{array}{c}99.999 \\
\text { (3.6 ppm } \\
\text { impurities) }\end{array}$} \\
\hline $\begin{array}{c}\mathrm{N}_{2} \mathrm{H}_{4}, \\
\text { double } \\
\text { reduction }\end{array}$ & 1.04 & 0.46 & $0.28-3.36$ & 0.54 & 0.85 & 2.12 & \\
\hline
\end{tabular}

\section{Hydrazine hydrate with PVP}

Polyvinylpyrrolidone is the most used dispersant for the nano and fine powder of silver preparation and one of the most effective. PVP with K value of 30 (26-35) with molecular weight of about 40.000 is used. Its water solutions are slightly acidic with specified $\mathrm{pH}$ from 3 to 6 for $5 \%$ by weight which is not optimal for reduction by $\mathrm{HH}$, which favour slightly basic conditions, but still acceptable. Viscosity of 5\% PVP in aqueous solution is $2.4 \mathrm{mPa} \cdot \mathrm{s}$ and for $2 \%$ is just slightly higher than water $(1.0 \mathrm{mPa} \cdot \mathrm{s})$. It is important that viscosity remains low to prevent agglomeration [14].

From data presented in Table 2. it can be concluded that PVP in the combination with hydrazine gives smaller particles than without it and with less wide size distribution. All particles are less than $2 \mu \mathrm{m}$ and average size is below $1 \mu \mathrm{m}$. Purity of silver is less than without using PVP and from analytical data is only disadvantage.

Figure 2. is more significant and shows details which could not be determined by analyzing individual particles or compact clusters. Several clusters with branched shape, narrow but grown in length, have dimensions from $1.5 \mu \mathrm{m}$ to even $4 \mu \mathrm{m}$ like prominent one little left from the centre of the picture.

Table 2. Statistical analysis of the particle sizes obtained by hydrazine reduction in the presence of PVP, given in the Figure 2.

\begin{tabular}{|c|c|c|c|c|c|c|c|}
\hline \multirow{2}{*}{$\begin{array}{l}\text { Reduction } \\
\text { agent/ } \\
\text { dispersant }\end{array}$} & \multirow{2}{*}{$\begin{array}{l}\text { Average } \\
\text { particle } \\
\text { size, } \mu \mathrm{m}\end{array}$} & \multirow{2}{*}{$\begin{array}{c}\text { Standard } \\
\text { deviation, } \\
\mu \mathrm{m}\end{array}$} & \multirow{2}{*}{$\begin{array}{l}\text { Particle } \\
\text { size, from } \\
\text { to, } \mu \mathrm{m}\end{array}$} & \multicolumn{3}{|c|}{$\begin{array}{c}\text { Particle size } \\
\text { distribution, } \mu \mathrm{m}\end{array}$} & $\begin{array}{c}\text { Silver } \\
\text { purity, } \%\end{array}$ \\
\hline & & & & D10 & D50 & D90 & \multirow{2}{*}{$\begin{array}{c}99.999 \\
(7.4 \mathrm{ppm} \\
\text { impurities) }\end{array}$} \\
\hline $\begin{array}{l}\mathrm{N}_{2} \mathrm{H}_{4}, \\
\text { PVP }\end{array}$ & 0.71 & 0.39 & $0.33-1.92$ & 0.38 & 0.59 & 1.23 & \\
\hline
\end{tabular}

Shape of the individual particles is irregular but near spherical. Long clusters could discard the powder as one with fine particles, less than $2.5 \mu \mathrm{m}$. One of the reasons for agglomeration is probably $\mathrm{pH}$ value out of the optimal.

\section{Hydrazine hydrate with SDS}

Sodium dodecyl sulfate is less frequent used dispersant. It is typical surfactant with many applications, especially in cosmetics for shampoos, toothpastes and numerous products for personal care. It is very soluble in water but with slow dissolving for higher concentrations (above 10\%). Drawback of the SDS as strong surfactant is its foaming ability, what is observed during the experiments even at relatively low applied concentration, $0.05 \mathrm{~mol} / \mathrm{dm}^{3}$. 


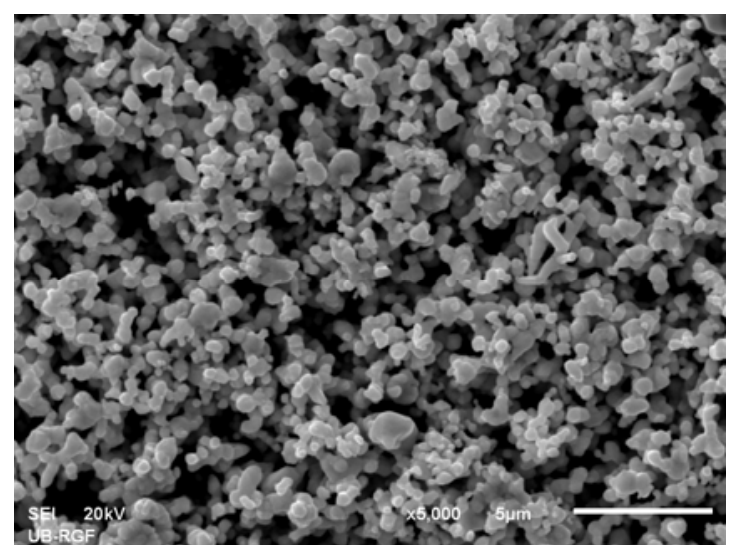

Fig. 2. SEM image of silver powder obtained by hydrazine reduction in the presence of $P V P$

In Figure 3, one can see obvious influence of the surfactant on morphology and size of the particles, compared with the reduction without it (Figure 1. and Table 1.). The particles are more spherical and smaller as shown in the Table 3. Individual particles are slightly and not significantly smaller than system with PVP as dispersant, but deviation is smaller and distribution is narrower.

Table 3. Statistical analysis of the particle sizes obtained by hydrazine reduction in the presence of SDS given in the Figure 3.

\begin{tabular}{|c|c|c|c|c|c|c|c|}
\hline \multirow{2}{*}{$\begin{array}{l}\text { Reduction } \\
\text { agent/ } \\
\text { dispersant }\end{array}$} & \multirow{2}{*}{$\begin{array}{c}\text { Average } \\
\text { particle } \\
\text { size, } \mu \mathrm{m}\end{array}$} & \multirow{2}{*}{$\begin{array}{c}\text { Standard } \\
\text { deviation, } \\
\mu \mathrm{m}\end{array}$} & \multirow{2}{*}{$\begin{array}{l}\text { Particle } \\
\text { size, from } \\
\text { to, } \mu \mathrm{m}\end{array}$} & \multicolumn{3}{|c|}{$\begin{array}{c}\text { Particle size } \\
\text { distribution, } \mu \mathrm{m}\end{array}$} & $\begin{array}{c}\text { Silver } \\
\text { purity, \% }\end{array}$ \\
\hline & & & & D10 & D50 & D90 & \multirow{2}{*}{$\begin{array}{c}99.999 \\
\text { (8.3 ppm } \\
\text { impurities) }\end{array}$} \\
\hline $\begin{array}{c}\mathrm{N}_{2} \mathrm{H}_{4} \\
\text { SDS }\end{array}$ & 0.62 & 0.33 & $0.19-1.44$ & 0.28 & 0.46 & 1.15 & \\
\hline
\end{tabular}

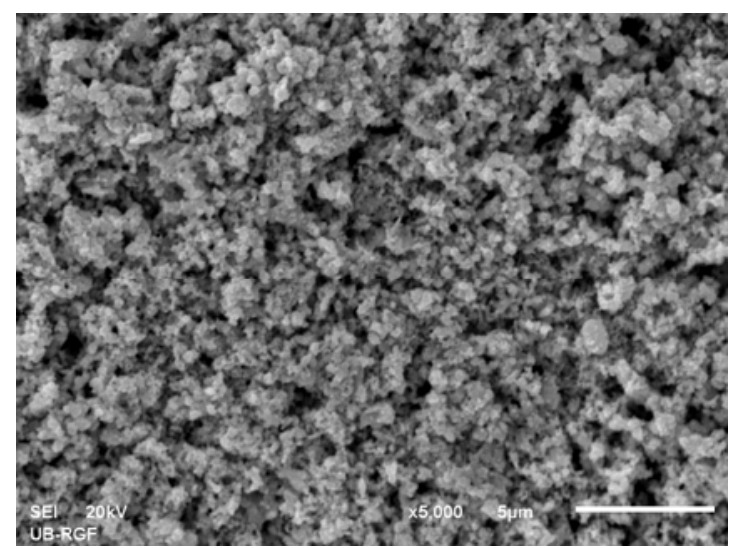

Fig. 3. SEM image of silver powder obtained by hydrazine reduction in the presence of SDS 
Presence of clusters is obvious and there are several of them, but fewer than with PVP. Difference is in their shape, since with SDS they have ellipsoid one not the linear, and with less than $2.5 \mu \mathrm{m}$ in diameter. This powder can be classified as fine one but not as spherical and monodisersed. It should be noted that the purity of sliver decreases when dispersant is applied and for the SDS is lower than when PVP is used.

\section{Reduction with ascorbic acid}

Ascorbic acid is commonly used reducing agent [10, 13, 17-19] for preparation of fine silver power, silver microcrystals and silver nanoparticles. Silver ions were reduced to metal silver by ascorbic acid $\left(\mathrm{C}_{6} \mathrm{H}_{8} \mathrm{O}_{6}\right)$ according to the following reaction:

$$
\mathrm{C}_{6} \mathrm{H}_{8} \mathrm{O}_{6}+2 \mathrm{Ag}^{+} \rightarrow 2 \mathrm{Ag}+\mathrm{C}_{6} \mathrm{H}_{6} \mathrm{O}_{6}+2 \mathrm{H}^{+}
$$

This reaction is easily to control since the middle reduction power of the reducent [13]. Ascorbic acid is full alternative for hydrazine, except in the case of very dilute solutions and for quantitative reduction of $\mathrm{Ag}^{+}$ions.

\section{Ascorbic acid with PVP}

Combination of ascorbic acid and PVP is very usual for the synthesis of silver nanoparticles, frequently combined with visible light for photoinduced or photocatalytic reduction [4]. AA (Ascorbic acid) as reducing agent is very suitable for controlling the morphology of silver nanoparticles or microcrystals. For instance, just the simple variation of concentration has influence on morphology since the reduction of AgNO3 is accelerated at a high concentration of ascorbic acid, which is beneficial in the formation of dendrites [20]. In contrast, the rate of nucleation will be decrease at a low concentrations and with the aid of surfactant molecules, the silver clusters preferentially growth could be controlled and consequently even the mechanisms that control particle morphology could be set [21]. Slightly acidic pH value (4.4) of PVP solution is beneficial since average congeries sizes (D50) reduces as the $\mathrm{pH}$ value increases above value of 4 and the optimal is in the range 4-6 [13].

Figure 4. is clear evidence that the process of agglomeration is multistage as stated above. Different "generation" of particles could be seen. Smaller particles ranging from 0.25 to $0.30 \mu \mathrm{m}$ build larger conglomerates or clusters which consist of several (8-20) of them and is countable from the picture for some of them. Larger clusters with dimensions about $2 \times 3 \mu \mathrm{m}$ is not used for the particle size distribution given in Table 4. It is in the aim of the possibility to improve the method easily what could be assumed form the results. The smallest particles are spherical and larger are mainly simple polyhedral shapes or ellipsoidal cluster structure. 


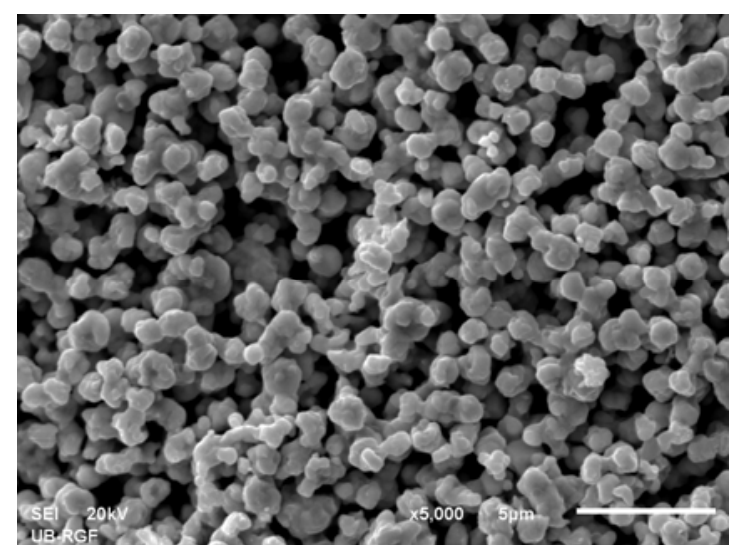

Fig. 4. SEM image of silver powder obtained by ascorbic acid reduction in the presence of PVP

Table 4. Statistical analysis of the particle sizes obtained by ascorbic acid reduction in the presence of PVP, given in the Figure 4.

\begin{tabular}{|c|c|c|c|c|c|c|c|}
\hline Reduction & \multirow{2}{*}{$\begin{array}{c}\text { Average } \\
\text { agent/ } \\
\text { dispersant }\end{array}$} & $\begin{array}{c}\text { particle } \\
\text { size, } \mu \mathrm{m}\end{array}$ & $\begin{array}{c}\text { Standard } \\
\text { deviation, } \\
\mu \mathrm{m}\end{array}$ & $\begin{array}{c}\text { Particle } \\
\text { size, from } \\
\text { to, } \mu \mathrm{m}\end{array}$ & \multicolumn{2}{|c|}{ Particle size } & \multicolumn{2}{|c|}{$\begin{array}{c}\text { Silver } \\
\text { distribution, } \mu \mathrm{m}\end{array}$} & Durity, \% \\
\hline $\begin{array}{c}\text { Ascorbic } \\
\text { acid, PVP }\end{array}$ & 0.70 & 0.28 & $0.15-1.75$ & 0.25 & 0.67 & 1.08 & $\begin{array}{c}\text { D50 } \\
\text { impurities })\end{array}$ \\
\hline
\end{tabular}

Standard deviation and particle size distribution suggest possible the narrowest particle size distribution for the agents, in particular experiment is true without larger clusters. Not just data but the picture shows similar size of many particles mainly in the range of 0.70 to $0.90 \mu \mathrm{m}$.

\section{Ascorbic acid with SDS}

Sodium dodecyl sulfate (SDS) or sodium lauryl sulfate (SLS), $\mathrm{CH}_{3}\left(\mathrm{CH}_{2}\right)_{11} \mathrm{OSO}_{3} \mathrm{Na}$ is an anionic surfactant and thus its solution in water should be slightly basic, $7.5-8.5$ by product specifications for 5 or $10 \%$ concentrations. Solution used in experiments (approx. 1.4\% wt.) has $\mathrm{pH}$ of 7.23 what can be consider neutral. It is important in the means of optimum $\mathrm{pH}$ for the minimal particle size since solutions were not buffered. On the end of the experiment solution has $\mathrm{pH}$ of 5.76, at the upper edge of the optimal range.

The smallest particle size but wide size distribution (Table 5.) could be seen in the Figure 5. Various shapes are also characteristic of the powder obtained by combination of AA and SDS (SLS). Particles are mainly irregular but with spherical, needle like, linear and polyhedral ones. 


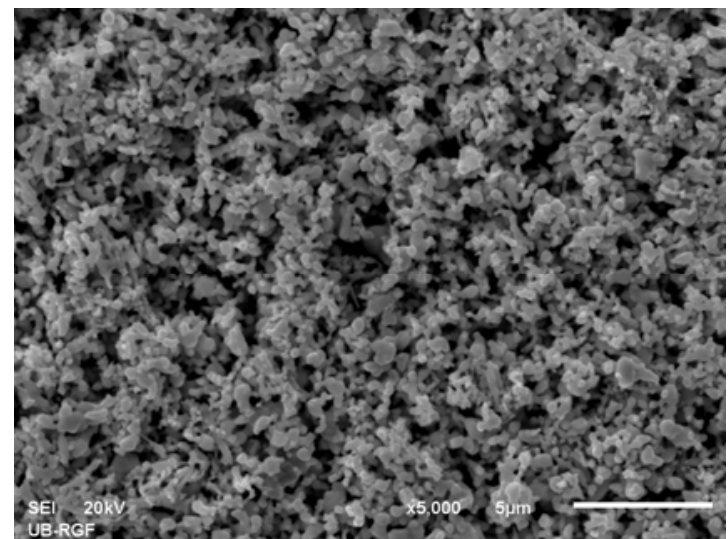

Fig. 5. SEM image of silver powder obtained by ascorbic acid reduction in the presence of $S D S$

Table 5. Statistical analysis of the particle sizes obtained by ascorbic acid reduction in the presence of SDS, given in the Figure 5 .

\begin{tabular}{|c|c|c|c|c|c|c|c|}
\hline \multirow{2}{*}{$\begin{array}{l}\text { Reduction } \\
\text { agent/ } \\
\text { dispersant }\end{array}$} & \multirow{2}{*}{$\begin{array}{l}\text { Average } \\
\text { particle } \\
\text { size, } \mu \mathrm{m}\end{array}$} & \multirow{2}{*}{$\begin{array}{c}\text { Standard } \\
\text { deviation, } \\
\mu \mathrm{m}\end{array}$} & \multirow{2}{*}{$\begin{array}{l}\text { Particle } \\
\text { size, from } \\
\text { to, } \mu \mathrm{m}\end{array}$} & \multicolumn{3}{|c|}{$\begin{array}{c}\text { Particle size } \\
\text { distribution, } \mu \mathrm{m}\end{array}$} & $\begin{array}{c}\text { Silver } \\
\text { purity, \% }\end{array}$ \\
\hline & & & & D10 & D50 & D90 & \multirow{2}{*}{$\begin{array}{c}99.999 \\
(9.2 \mathrm{ppm} \\
\text { impurities) }\end{array}$} \\
\hline $\begin{array}{l}\text { Ascorbic } \\
\text { acid, SDS }\end{array}$ & 0.51 & 0 & $0.12-1.18$ & 0.16 & 0.43 & 0.94 & \\
\hline
\end{tabular}

SDS with ascorbic acid results in lowest (average) particle size from all other combination of previous two reducing agents and dispersants. Particle size distribution indicates the best results as well. Clusters are similar as in the AA/PVP combination but smaller and with less small particles in it, even just as little as six. Silver purity is the lowest of all experiments but still fully meets the requirements for $5 \mathrm{~N}(99.999 \%)$ quality.

\section{Ascorbic acid with sodium citrate}

Sodium citrate has double effect in the precipitation of silver powder when coupled with ascorbic acid as reducing agent and as $\mathrm{pH}$ regulator. It is the weak reducing agent and it reduces silver according to the reaction [3]:

$$
4 \mathrm{Ag}^{+}+\mathrm{C}_{6} \mathrm{H}_{5} \mathrm{O}_{7} \mathrm{Na}_{3}+2 \mathrm{H}_{2} \mathrm{O} \rightarrow 4 \mathrm{Ag}+\mathrm{C}_{6} \mathrm{H}_{5} \mathrm{O}_{7} \mathrm{H}_{3}+3 \mathrm{Na}^{+}+\mathrm{H}^{+}+\mathrm{O}_{2}
$$

It is usually used without surfactant and with no ascorbic acid [3, 4] but could be used in combination with AA but without mixing them together but respectively [22] as were done in the experiments. This combination is used for special applications such as synthesis of silver nanodisks in solution where at high concentrations of ascorbic acid where acerbate anions could play roles both as a reducing agent and as a capping ligand in the absence of external additives just as the roles played by citrate anions [17]. 
Since its weak base characteristic, trisodium citrate influence on the strength of $\mathrm{AA}$ as reducing agent since the redox potential of the AA is affected with the $\mathrm{pH}$ of the solution.

$$
\begin{aligned}
& \mathrm{C}_{6} \mathrm{H}_{6} \mathrm{O}_{6}+2 \mathrm{H}^{+}+2 e \leftrightarrow \mathrm{C}_{6} \mathrm{H}_{8} \mathrm{O}_{6} \\
& E=E^{0}-0.059 \mathrm{pH}
\end{aligned}
$$

According to Eq. (6), value of redox potential becomes smaller with the increase of $\mathrm{pH}$ value, and consequently the reducing power of AA becomes stronger. Thus the reduction rate for the reaction of can be adjusted by changing $\mathrm{pH}$ value [10]. In this case concept was to reduce reduction power of the AA and to slow down the reaction. For instance, redox potential of AA on $\mathrm{pH}=4.47$ is $+0.158 \mathrm{~V}$ vs. SHE ( $\mathrm{pH}$ for the start of reduction by $\mathrm{AA}$ without sodium citrate) and rising till end of the reduction but on $\mathrm{pH}=6.56$ is $+0.035 \mathrm{~V}$ (final $\mathrm{pH}$ of the solution when silver is reduced with combination of sodium citrate and AA).

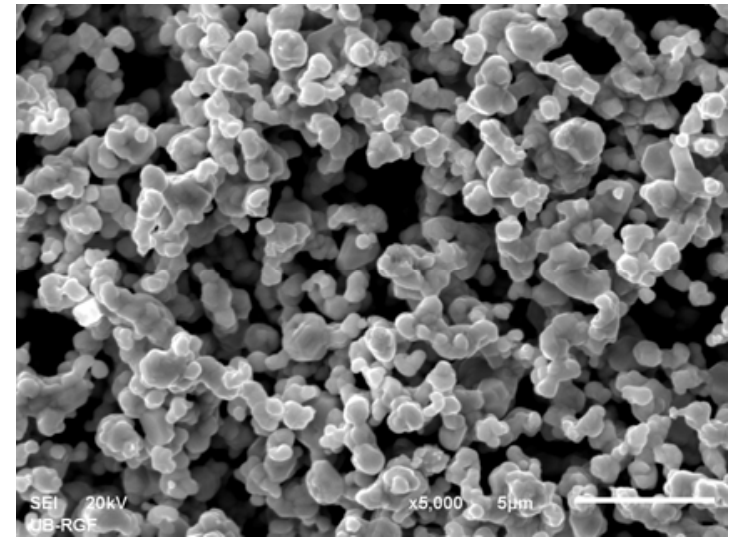

Fig. 6. SEM image of silver powder obtained by combined reduction by ascorbic acid and trisodium citrate

Similar with previous two (Figures 4. and 5.), agglomeration is obvious in Figure 6 , but with clusters usually smaller than $2 \mu \mathrm{m}$ and rarely with length of about $3 \mu \mathrm{m}$. Clusters are formed by smaller "primarily" particles (although they are already aggregates of nano particles) with size of 300 to $400 \mathrm{~nm}$ (Table 6). Particles are irregular or near spherical and clusters are linear, ellipsoidal or nearly spherical.

Table 6. Statistical analysis of the particle sizes obtained by combined reduction by ascorbic acid and trisodium citrate, given in the Figure 6.

\begin{tabular}{|c|c|c|c|c|c|c|c|}
\hline \multirow{2}{*}{$\begin{array}{c}\text { Reduction } \\
\text { agent }\end{array}$} & \multirow{2}{*}{$\begin{array}{c}\text { Average } \\
\text { particle } \\
\text { size, } \mu \mathrm{m}\end{array}$} & $\begin{array}{c}\text { Standard } \\
\text { deviation, } \\
\mu \mathrm{m}\end{array}$ & $\begin{array}{c}\text { Particle } \\
\text { size, from } \\
\text { to, } \mu \mathrm{m}\end{array}$ & \multicolumn{3}{|c|}{ Particle size distribution, } & \multicolumn{2}{|c|}{$\begin{array}{c}\text { Silver } \\
\text { purity, \% }\end{array}$} \\
\cline { 5 - 7 } & & & $\mathrm{D} 10$ & $\mathrm{D} 50$ & $\mathrm{D} 90$ & \\
$\begin{array}{c}\text { Ascorbic } \\
\text { acid and } \\
\text { sodium } \\
\text { citrate }\end{array}$ & 0.86 & 0.49 & $0.16-2.34$ & 0.37 & 0.75 & 1.65 & $\begin{array}{c}\text { (4.5 ppm } \\
\text { impurities })\end{array}$ \\
\hline
\end{tabular}


Average particle size is smaller only when compared with double reduction with hydrazine, and particle distribution follow the same pattern with similar values. Particle sizes varied from as small as $150 \mathrm{~nm}$ up to more than $2 \mu \mathrm{m}$ with higher (standard) deviation of all samples. Purity of silver is inferior only to hydrazine hydrate without surfactant and better than all other samples.

\section{Determination of silver purity}

Two methods were used for the purpose. Dispersive X-ray Spectroscopy (EDS) and ICP-AES. EDS Spectrum is practically identical for all silver powders and is shown in the Figure 7. In all experiments, purity was $100.00 \%$.

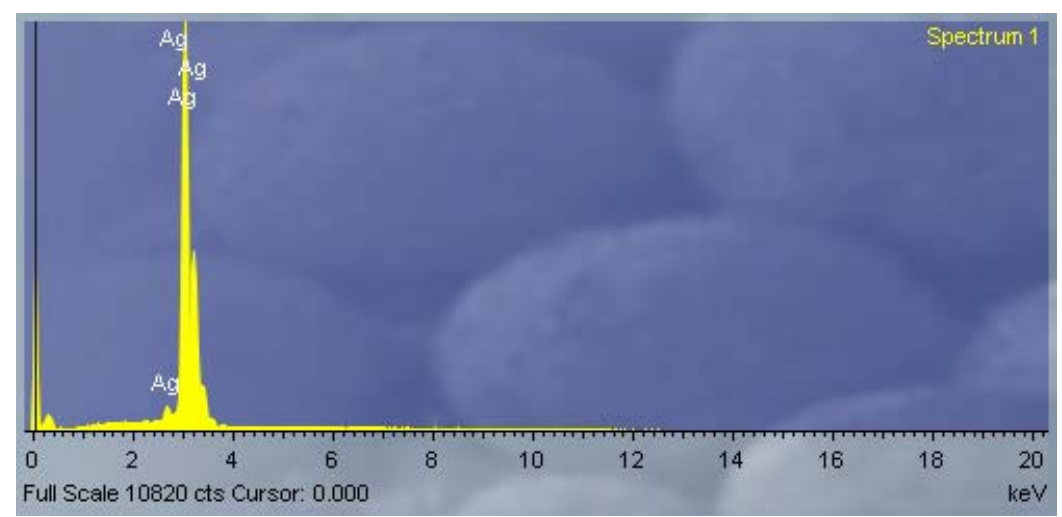

Fig. 7. Typical EDS Spectrum for the silver powder obtained by double reduction

In the aim to get better precision ICP-AES were used and the results are given in Tables 1. to 6. in the last columns of them.

\section{Conclusion}

Chemical reduction ("wet chemical" method) is well established for the preparation for silver nanopowder and fine powder. On the basis of the obtained results, the following conclusions can be made:

- In the all experiments more than $90 \%$ of particles have dimension smaller than $2.5 \mu \mathrm{m}$ and could be conditionally classified as fine powders. Reduction without assistance of the dispersants causes faster agglomeration and more coarse particles. Surfactants exhibited a significant influence on just on particle size but also on the morphology of the silver crystals;

- PVP as dispersant is showed very similar performance for both reducing agents. Average sizes of the particles were very similar: 0.71 and $0.70 \mu \mathrm{m}$ for hydrazine hydrate and ascorbic acid respectively, but the size distribution for the ascorbic acid was narrower;

- SDS performed better, especially when ascorbic acid was the reducing agent. That powder had fair distribution of size and their size was smaller with more than $50 \%$ of particles below $500 \mathrm{~nm}$ and mostly in the range of 300 to $700 \mathrm{~nm}$;

- Purity of silver is higher after hydrazine hydrate without surfactant indicates that use of them results in lower purity of silver, but with marginal difference. Additional reduction, performed in all experiments, is necessary for the higher 
purity of silver and is suitable for "5N" quality of silver, when the $99.99 \%$ silver were dissolved for the reduction;

- Sodium citrate provides extensive control over reaction and the standard procedure could be improved by adjusting the $\mathrm{pH}$ value with diluted solutions of $\mathrm{HCl}$ and ammonia or $\mathrm{NaOH}$.

Through research it was confirmed that this process is not just adequate from technical point of view but also is sufficiently simple and economical. Process is also not demanding for the equipment.

\section{Acknowledgment}

This work has resulted from the project funded by the Ministry of Education and Science of the Republic of Serbia, No 34033 on which the authors of this occasion want to thank.

\section{References}

[1] R. McGrath, International Journal of Powder Metallurgy - Focus Issue: Precious Metals, Platinum Metals Rev., 54, (2), 122-124, 2010

[2] A. Ivanović, S. Dimitrijević, S. Dimitrijević, B. Trumić, V. Marjanović, J. Petrović, N. Vuković, Electrodeposition of silver powder from nitrate electrolyte for usage in electronic Optoelectronics and Advanced Materials - Rapid Communications, 6, (3-4), 465-473, 2012

[3] A. A. El-Kheshen, S. F. Gad El-Rab, Effect of reducing and protecting agents on size of silver nanoparticles and their anti-bacterial activity, Der Pharma Chemica, 4(1):53-65, 2012

[4] W. Zhang, X. Qiao, J. Chen, Synthesis of silver nanoparticles-Effects of concerned parameters in water/oil microemulsion, Materials Science and Engineering B 142, 1-15, 2007

[5] S. Stopić, P. Dvorak, B. Friedrich, Synthesis of spherical nanosized silver powder by ultrasonic spray pyrolysis, Metall, 60, 6, 299-304, 2006

[6] A. Bing, C. Xiong-hui, W. Feng-shun, W. Yi-ping, Preparation of micro-sized and uniform spherical $\mathrm{Ag}$ powders by novel wet-chemical method, Trans. Nonferrous Met. Soc. China 20, 1550-1554, 2010

[7] M. Filipović, Ž. Kamberović, Endre Romhanji, Structure and kinetics of internal oxidation in Ag-Sn alloys, Metalurgija - Journal of Metallurgy, 14, (3) 2008

[8] F. Heringhaus, P. Braumann, D. Rühlicke, E. Susnik, R. Wolmer, Konf.Proc. $20^{\text {th }}$ ICEC, Stockholm, 199-204, 2000

[9] N. Moudirab, Y. Boukennousb, N. Moulaï-Mostefaac, I. Bozetineb, M. Maoudjb, N. Kameld, Z. Kameld, D. Moudird, Preparation of silver powder used for solar cell paste by reduction process, TerraGreen 13th International Conference 2013 - Advancements in Renewable Energy and Clean Environment, Energy Procedia 36, 1184-1191, 2013

[10] Z. Liu, X. Liang, H. Wang, Synthesis and characterization of spherical and mono-disperse micro-silver powder used for silicon solar cell electronic paste, Advanced Powder Technology, 23, 250-255, 2012 
[11] S. B. Rane, V. Deshapande, T. Seth, G. J. Phatak, D. P. Amalnerkar, B. K. Das, Synthesis of submicron size silver powder for passive components application, Powder Metallurgy and Metal Ceramics, Vol. 43, Nos. 9-10, 2004

[12] E. Nisaratanaporn, K. Wongsuwan, Preparation of ultrafine silver powder using glycerol as reducing agent, Journal of Metals, Materials and Minerals, Vol.18 No.2 pp.1-5, 2008

[13] W. Songping, M. Shuyuan, Preparation of ultrafine silver powder using ascorbic acid as reducing agent and its application in MLCI, Materials Chemistry and Physics 89, 423-427, 2005

[14] V. Privman, D. V. Goia, J. Park, E.Matijević, Mechanism of Formation of Monodispersed Colloids by Aggregation of Nanosize Precursors, Journal of Colloid and Interface Science 213, 36-45, 1999

[15] A. T. Ankus, R. D. Venter, The water atomization of silver: effect of pressure and superheat, Powder Technology, 73, 69-179, 1992

[16] Busch, Walter O., Sepulveda, Aquiles O., Powder production by high-pressuregas atomization, Advances in Powder Metallurgy, 2, 97-109, 1989

[17] J. Yang, L. Qi, D. Zhang, J. Ma, H. Cheng, Dextran-controlled crystallization of silver microcrystals with novel morphologies, Crystal Growth \& Design, 4(6), 1371-1375, 2004

[18] N. Elizondo, Paulina Segovia, V. Coello, J. Arriaga, S. Belmares, A. Alcorta, F. Hernández, R. Obregón, E. Torres, F. Paraguay, Green synthesis and characterizations of silver and gold nanoparticles, Green Chemistry Environmentally Benign Approaches, Chapter 8 Green Synthesis and Characterizations of Silver and Gold Nanoparticles, Intech, 139-157, 2012

[19] A. Stroia, C. Matei, B. S. Vasile, O. Oprea, C. Covaliu, I. Jitaru, a new route for synthesis and characterization of macroporous granular silver, U.P.B. Sci. Bull., Series B, 74 (3), 7-18, 2012

[20] T. Fukuyo, H. Imai, Morphological evolution of silver crystals produced by reduction with ascorbic acid, Journal of Crystal Growth 241, 193-199, 2002

[21] E. Leontidis, Konstantina Kleitou, T. Kyprianidou-Leodidou, V.Bekiari, P.Lianos, Gold Colloids from Cationic Surfactant Solutions. 1. Mechanisms That Control Particle Morphology, Langmuir, 18, 3659-3668, 2002

[22] H. Tavallali, S. Pouresmaeil, Determination of ascorbic acid by modified method based on photoluminescence of silver nanoparticles, International Journal of hemTech Research CODEN (USA), 4 (1), 304-310, 2012 